\title{
Is Soliciting Important in Science? An Investigation of Science Teacher - Student Questioning Interactions
}

\author{
Ajaja O. Patrick \\ Department of Science Education, Delta State University \\ Abraka, Nigeria \\ E-mail: osawaruajaja@yahoo.com \\ Eravwoke Ochuko Urhievwejire \\ Department of Educational Psychology and Curriculum Studies \\ University Of Benin, Benin City, Nigeria \\ E-mail: ejiroeravwoke@yahoo.com
}

Received: June 15, 2011

Accepted: June 28, 2011

Published: February 1, 2012

doi:10.5539/ies.v5n1p191

URL: http://dx.doi.org/10.5539/ies.v5n1p191

\begin{abstract}
The major purpose of this study was to determine the questioning patterns of teachers in science classes. The design employed for the study was a case study. To guide this study, five research questions were asked and answered. The samples of the study consisted of 20 senior secondary schools and 60 science teachers. The instruments used for data collection were Science Class Questioning Categories. The major findings of the study included: $21.4 \%$ of science instructional time was spent on questioning; most of the questions asked in science classes were on knowledge; there were significant differences between male and female teachers on questions asked on knowledge and analysis; the bulk of questions asked in science classes were directed at the male and high ability students; and most of the questions asked in science classes received an average wait-time of 3 seconds. It was concluded that questions remain the most vital tool for determining students understanding.
\end{abstract}

Keywords: Questioning, Pattern, Sex, Wait-time, Proportion, Transfer

\section{Introduction}

The essence of emphasis on activity centered science teaching comprises two main elements: arrange the learning environment to facilitate student-centered instruction and give sufficient guidance to ensure direction and success in discovering scientific concepts and principles. One way in which a teacher helps students to obtain a sense of direction and to use their minds is through questioning. The art of being a good conversationalist requires listening and insightful questions. Good science teachers are excellent conversationalists. They listen well and ask appropriate questions, assisting individuals in organizing their thoughts and gaining insights. A properly given question is a hint (Trowbridge and Bybee, 1996).

In the context of a lively and fast-paced exchange in a classroom, questions are not always obvious (Borich, 2004). As observed by Brown and Wragg (1993), students routinely report difficulty in distinguishing some types of questionings in the context of classroom dialogue - and even whether a question has been asked. In the light of this, effective questions should be asked to provide appropriate directions. Effective questions are ones which students actively compose a response and thereby become engaged in the learning process (Chuska, 1995; Wilen, 1991).

Questions may be planned before a lesson or may arise spontaneously because of students interaction. It is always proper to prepare a series of questions before any science lesson. The fact that a teacher has done so contributes to his questioning ability. Having thought about the questions, it gives the right direction and a sense of security, thus enhancing the appropriate ability to carry on discussion in the classroom.

Science teachers must remain constantly flexible. Even though they have planned a series of questions, they must be willing to deviate from them and formulate new ones as they interact with students. Most often, the kinds of questions asked in any science classroom are influenced by the following:

1) talents to be developed; 
2) critical thinking processes to be nurtured;

3) subject - matter objectives to be developed;

4) types of answers to be accepted;

5) skills to be developed; and

6) attitudes and values to be emphasized.

In almost any classroom at any time, one can observe a sequence of events in which the teacher structures the content to be discussed, solicits a student response, and then reacts to be the response. These activities performed in sequence are the most common behaviors in any science classroom. The teacher behavior in this chain of events compose the activities of structuring, soliciting, and reacting. At the heart of this chain (Borich, 2004) is soliciting, or question-asking behavior. Questions are the tool for bridging the gap between presentation of content and students understanding of it. Sometimes as much as $80 \%$ of all school time (Borich, 2004) can be devoted to questions and answers. This enormous concentration on a single strategy attests both to its convenience and to its perceived effectiveness.

It would be easy to classify all questions as either lower order (requiring the recall of information) or higher order (requiring clarification, expansion, generalization, and inference). Another way to classify question is to determine whether they are convergent or divergent questions. A question that limits an answer to a single or small number of responses is called a convergent (or direct or closed) question (Borich, 2009). The question that encourages a general or open response is called divergent (or indirect) questions. But these broad distinctions would ignore the many specific purposes for which questions are used. Most reasons for asking questions in science classes are to achieve the following specific objectives:

1) Interest getting and attention getting;

2) diagnosing and checking;

3) recall of specific facts or information;

4) managerial

5) encourage higher-level thought process;

6) structure and redirect learning; and

7) allow expression of affect.

Some research evidences show that not all questions asked in the class by teachers actively engage students in the learning process. Early studies estimated that $70 \%$ to $80 \%$ of all questions asked in the class require the simple recall of facts; only $20 \%$ to $30 \%$ require the higher-level thought processes of clarifying, expanding, generalizing and making inferences (Corey, 1940; Haynes, 1935). Evidently little has changed since these early studies (Borich, 2004). Recent work in United States and England indicates that, of every five questions asked, about three require data recall, one is managerial, and only one requires higher-level thought processes (Atwood and Wilen, 1991, Brown and Wragg, 1993; Wilen, 1991). This situation may not be different from what is going on in our science classes. Replication of studies in United States and Europe to determine if there are variations in their findings with the situation in our environment informed this study.

The lopsided proportion of recall questions to thought questions is alarming. Behaviours most frequently required in adult life, at work, and in advanced training those at the high levels of cognitive complexity involving analysis, synthesis, and evaluation - seem to be the least emphasized behaviours in the classroom (Power and Hubbard, 1999; Risner, Skeel and Nicholson, 1992).

Most questions have the purpose of shaping or setting up the learner's response. A well-framed question in a science class will serve as an advance organizer, providing the framework for the response that is to follow. In this study, attempt will be made to determine the following:

i. types of questions asked in science classroom;

ii. percentage of class time spent questioning;

iii. if types of questions asked are influenced by teachers' sex;

iv. who are targets of questions; and

v. Wait-time science teachers allow in the classroom. 


\section{Statement of the Problem}

Literature on types of questions asked in the classrooms indicate that as high as between $70 \%-80 \%$ of the questions asked center on recall of facts and information. Only $20 \%-30 \%$ of the questions require higher-level responses. This trend has not changed even when compared with the studies in the 1930s and 1940s. Most of the studies on questioning are concentrated on general classroom situation instead of being narrowed to fields and disciplines. There is limited literature in Nigeria on questioning in science classrooms. The much we know about questioning in science classes are findings on studies carried out in Europe and America, the findings of which may not be similar with our environment. The situation therefore calls for more indigenous and discipline localized studies to increase our knowledge on what goes on during questioning particularly in science classrooms.

The statement of the problem therefore centres on whether the observation of a science class provides clues on: types of questions asked, percentage of class time spent questioning, if there is sex baise in the types of questions asked by male and female teachers, who are targets of questions and wait - time on questions.

\section{Research Questions}

To guide this study, the following research questions were raised:

1) What proportion of science class time is spent questioning?

2) What is the pattern of questioning in science classes?

3) Is pattern of questioning in science classes influenced by teachers' sex?

4) Who are targets of questions asked in science classes?

5) What wait-time do science teachers allow in science classes?

\section{Methodology}

\subsection{Design of the Study}

The design employed in finding out the questioning patterns of science teachers in science classes was case study. The non-participant observation design was the kind of case study employed. This approach was most suitable since the researcher was not part of the activity or phenomenon being studied. The observer merely coded the questioning patterns of the science teacher as the lesson goes on.

\subsection{Population and Sample of the Study}

The population of school of study consisted of all the Public Senior Secondary Schools in Ika "nation" made of the Ika South and Ika North East Local Government Areas of Delta State, Nigeria. There are 32 public senior secondary schools in the two local government areas made of 17 in Ika South and 15 in Ika North East. The population of the science teachers consisted of all the teachers teaching biology, chemistry and physics in the senior secondary schools. All the science students in the public schools in the two local government areas constituted the students population.

The samples of the study consisted of 20 mixed public senior secondary schools and 60 science teachers randomly selected. All the single sex senior secondary schools were isolated from the study because of the intension to determine if questions asked in the science classes were mostly targeted at males or females. In each of the sampled schools, 3 science classes teachers were randomly selected to reflect one biology, chemistry and physics teachers.

\subsection{Instrument}

The instruments used for the study are two: (i) Science Class Questioning Categories (SCQC); and (ii) Students Past results in Biology, Chemistry and Physics. The Science Class Questioning Categories is a questioning behaviour checklist constructed by the researchers. The checklist is an observational instrument designed specifically for use in science classroom to assess the questioning behaviour patterns of science teachers. See appendix 1. Observers using the SCQC system code the questioning behaviours of a science teacher every 2-4 seconds using codes representing three dimensions as:

1) what is the specific nature of the questions being asked?

2) to whom is a specific question being directed?

3) what is the ability of the student to whom the questions are being directed? and

4) what wait-time do science teachers allow?

The SCQC is made of 11 individual categories of teacher questioning behaviour which represent the fine structure details of six classes of questions using Bloom's taxonomy of cognitive objectives. These broad Bloom's taxonomy 
categories of questions include questions demanding: Knowledge, Comprehension, Application, Analysis, Synthesis and Evaluation. The SCQC also asked questions on sex and ability of students to whom questions are directed and wait-time science teachers allow.

The second instrument is the students past results in Biology, Chemistry and Physics. The students past results had their specific names written against their scores. Using the students' scores, they were divided into three groups of abilities: high, middle, and low achievers. Students with score ranging from 60-100 were regarded as high achievers, students with scores from 45-59 were regarded as middle achievers while students with scores ranging from 1-44 came under low achievers.

The validity of the SCQC was determined by a panel of five judges: 3 science teachers (Biology, Chemistry and Physics), 1 science educator and 1 Measurement and Evaluation expert. Their duty was to determine the content validity of the instrument and relate it with the objectives to be achieved with the instrument. The research questions acted as a guide in the execution of their assignments. After few corrections in the instrument arising from the judges comments, the instrument was used for the study.

The students past results in Biology, Chemistry and Physics were not validated as the scores were collected from the original source. Since the records were got from the original source, they were adjudged as reliable and valid.

The reliability of the SCQC was determined by adopting inter-rater reliability format. This involved first the determination of the correlation coefficient of the first and second ratings of five randomly selected science teachers in five senior secondary schools in Ukwuani Local Government Area by one of the four raters used for the study. This was followed by pooling together the ratings of the four raters and applying the inter-rater reliability formula. This formula was adopted following the recommendations of Wiseman (1999); Johnson and Christensen (2000) and Thorndike and Hagen (1997) that if several judges are available who have equal competence with the materials to be rated or equal familiarity with the ratee if the ratings are of a person, then a pooling of their ratings will produce a composite that is more reliable. The reliability obtained on application of the formula was 0.74 which is acceptable.

\subsection{Training of Raters}

For the coding of the science teachers questioning pattern, the researchers recommended that observers should act as non-participant observers. The researchers together with four selected raters (observers) went through the items in the SCQC a week before the commencement of the study to specify what to code and where to code. It was recommended that at most 10 science teachers be observed by each rater per week and for 6 weeks. This means that each rater will observe all selected science teachers in all the selected schools. Each science teachers while teaching should be observed for 45 minutes. As the science lesson progressed, using the SCQC checklist, each observer should make appropriate strokes next to the appropriate categories every 3 seconds, for A - J. After the class, the frequency of occurrence of the categories for each science teacher observed was recorded.

\subsection{Data Collection Procedure}

The questioning patterns of 60 science teachers of three subjects (Biology, Chemistry and Physics) in twenty (20) senior secondary schools from Ika South and Ika North East Local Government Areas of Delta State were collected for six weeks using the Science Class Questioning Categories (SCQC). The observers were made of a team of six persons which included; the researchers, and four trained raters (observers). Each of the science teachers was observed for 45 minutes. During each science lesson, the rater made strokes next to the appropriate categories every 3 seconds on the SCQC for items A-J for each science teacher observed. The observer specified the wait-time teachers allowed for category $\mathrm{K}$.

After the science class, the frequency of occurrence of the categories for each of the science teacher observed was recorded and the average scores for all the individuals rated were noted.

All the research questions were answered with simple percentages. However; research question 3 was further answered after the application of F-test at 0.05 level of significance on data collected which are related to the question.

\section{Results}

Shown in table 1, the amount of science class time on questioning was 21.4 minutes which constituted $47.97 \%$ of the class time. The table showed no consistency in the amount of class time spent questioning in the respective science subjects.

Table 2 which compared the amount of class time spent asking varying categories of questions, indicated that the highest percentage of class time spent questioning was on recall questions (knowledge). The questions on knowledge took as much as $68 \%$ of questioning time in science classes. Other lower level questions, like 
comprehension and application took $13.5 \%$ and $8 \%$ respectively of the class time spent questioning. For the higher level types of questions, the percentage time spent on them are; analysis $6 \%$, synthesis took $3 \%$ while evaluation took $1.5 \%$.

On comparison of amount of questioning time Female and Male science teachers spent on the various question types, table 3 indicated a similar pattern. Questions on knowledge took the highest percentage (Females 70\%, male 65\%) while question types on Comprehension, Application, Analysis, Synthesis and Evaluation sequentially followed behind. Questions on Evaluation among male and female teachers received the least percentage of questioning time. On comparison of questioning patterns of male and female science teachers, shown in table 4 , significant difference were found on knowledge $\mathrm{F}=5.44, \mathrm{P}<.05$, and Analysis $\mathrm{F}=4.81 ; \mathrm{P}<.05$.

Table 5 showed a very serious variation in the distribution of questions among students both on Sex and Ability. The table indicated that of the 761 questions asked in science classrooms, $503(66 \%)$ were directed at the male students while $258(34 \%)$ were directed at the female students. The table also indicated that $73 \%$ of the questions asked were directed at high ability students. Middle and low ability students received $18 \%$ and $9 \%$ respectively of the questions asked.

Shown in table 6, the range of wait-time on questions in science classes was from 2-4 seconds. The table indicated that in Biology class the wait-time on most of the questions was three seconds while the wait-time on most of the questions asked in Chemistry and Physics classes was four seconds. Generally, the table indicated that of the 761 questions asked, three seconds was spent as wait-time on 349 questions while two and four seconds wait-time were allowed for 169 and 244 questions respectively.

\section{Discussion}

The findings of this study are most significant in that they have increased our knowledge on the amount of time spent on questioning in science classes, the types of questions asked and the targets of questions in science classes. The study went a little further to compare the wait-time science teachers allowed in science classes in our environment.

Questions are tools to encourage students think about and act on the material teachers have structured. The center-piece of this chain - soliciting or questioning - is so prevalent that as many as 100 questions per class hour may be asked in a typical elementary and secondary classroom (Borich, 2009). The $21 \%$ of class time being devoted to questioning as shown in this study indicated that not enough questions are asked in science classes. This falls below international standards were sometimes as much as $80 \%$ of all school time can be devoted to questions and answers. The very low amount of class time being devoted to questioning is as a result of the method of instruction in science classes. In our science classes, the dominant method of instruction is lecture rather than inquiry/discovery (Ajaja, 2002). The lecture method requires the teacher to present content materials to students in its final form without actively engaging them.

Classroom researchers have studied the effects on student achievement of convergent and divergent questions (Cecil, 1995; Dillon, 1990; Gall, 1984). These studies found far more convergent questions raised in science classrooms than divergent questions. Higher-level, divergent-type questions perform the following functions; Promotion of thinking, formation of concepts and abstractions, encouragement of analysis-synthesis-evaluation and so on. Research has however, not clearly substantiated that the use of higher level questions is related to gains in student achievement; at least not as measured by tests of standardized achievement. Although some studies report modest improvements in achievement scores with the use of divergent questioning strategies, others have not. Some studies even reported larger achievement gains with convergent questioning than with divergent questioning strategies.

Research by Brown and Wragg (1993) suggests that questions at various levels of cognitive complexity can be directed to individuals, to groups, or to the entire class. Occasionally posing questions over the heads of some learners and under the heads of others will keep all students alert and engaged in the learning process. In a homogenously grouped class, questions can be spread across individuals, groups, and the full class but crafted to fit the cognitive complexity most appropriate for the learners being taught. This may be the reason why higher ability students are the target of most questions in science classrooms.

The noticed more questions being directed to males than females in science classes can be explained with the problem emanating from stereotypes differentials. Bennett (2003) stated that studies of classroom interactions have gathered evidence of differential treatment of girls and boys by some science teachers which resulted in the reaffirmation of stereotypes and discouraged girls from participating in science. For example, observation of interactions in science lessons showed that teachers spent more time interacting with boys than girls (Crossman, 1987). A marking exercise (Spear, 1987) yielded the disturbing result that teachers were more likely to award higher 
grades and more likely to predict success in science if thought the work had been done by a boy.

The finding of the high ability students being the main target of questioning in science classes indicated a serious defect in our teaching strategy where the top $10 \%$ constitute the major group catered for. The few questions being directed at the middle and low ability students agrees with the position of Ngeow (1998) that more advance organizers, hints, and clues will be more appropriate for some types of learners than for others. This explanation not withstanding, students who receive little or no attention from the class teacher soon feel rejected, frustrated and disinterested in learning.

Tharp (1989) report that different cultures often have different wait times. This may account for the different wait times found among teachers in the various science classrooms. This tended to suggest that content variations and variation in the methods of presentation of content materials to students in the various science subjects may have influenced their wait times. All the questions asked in science classes put together, indicated that the wait time on most of the questions is three seconds. This agrees with most research findings as noted by Trowbridge and Bybee (1996) that most instructors waited an average of three seconds for students to answer questions. An analysis of student responses revealed that teachers with longer wait-times (three seconds or more) obtained greater speculation, conversation, and argument than those with shorter wait-times. It is believed that expectancy levels of students are more likely to change positively if they are given a longer time to respond.

\section{Conclusion}

In almost any classroom at any time, you can observe a sequence of events in which the teacher structures the content to be discussed, solicits a students' response, and then reacts to the responses. These activities performed in sequence are the most common behaviours in any classroom. Questions remain a very important instrument for determining students understanding of a lesson.

Although different types of questions are asked in science classes with varying scopes and concentration, the bulk of questions asked centre on recall of facts. These types of questions constitute as much as $68 \%$ of all the questions asked.

The male students are the targets of most questions asked in science classes. The questions mostly directed to female students are low level questions demanding the recall of facts. This seems to give females a signal that they have low ability in the sciences (Barba and Cardinale, 1991).

An important consideration during questioning and probing is how long to wait before initiating another question. Sometimes your "wait-time" can be as effective in contributing to the desired response as the question or probe itself, especially when you give students time to thoughtfully compose their answers. It is concluded that teachers must determine the way they pose a question and the wait-time between questions and answers within the subject context and learning history of their learners.

\section{Reference}

Ajaja, O.P. (2002). Assessment of biology study support environment in our schools. In STAN $43^{\text {rd }}$ Annual Conference Proceeding, 215 - 218

Atwood, V., \& Wilen, W. (1991). Wait time and effective social studies instructions: What can research in science education tell us? Social Education, 55, 179 - 181.

Barba, R. \& Cardinale, L. (1991). Are females invisible students? An investigation of teacher- student questioning interactions. School science and Mathematics, 91(7): 306-310. http://dx.doi.org/10.1111/j.1949-8594.1991.tb12106.x

Bennett, J. (2003). Teaching and learning science. New York: Continuum.

Borich, G.D. (2004). Effective teaching methods, (fifth edition). New Jersey: Pearson Merrill Prentice Hall.

Borich, G.D. (2009). Effective teaching methods, (Ninth edition), New Jersey: Pearson Merrill Prentice Hall.

Brown, G. \& Wragg, E. (1993). Questioning. London: Routledge.

Cecil, N. (1995). The art of inquiry: Questioning strategies for $K-6$ classrooms. Iowa City, 1A: Portage and Main Press.

Chuska, K. (1995). Improving classroom questions: A teacher guide to increasing student motivation, participation and higher-level thinking. Bloomington, IN: Phi Delta Kappa Educational Foundation.

Corey, S. (1940). The teachers out-talk the pupils. School Review, 48, 745 - 752. http://dx.doi.org/10.1086/440596

Crossman, M. (1987). Teachers' interactions with girls and boys in science lessons. In A. Kelly (ed) Science for 
Girls? Buckingham: Open University Press.

Dillon, J. (1990). The practice of questioning. New York: Routledge.

Gall, M. (1984). Synthesis of research on questioning in recitation. Educational Leadership, 42(3), 40 - 49.

Haynes, H. (1935). The relation of teacher intelligence, teacher experience and type of school to type of questions. Unpublished doctoral dissertation, George Peabody College for Teachers, Nashville, TN.

Johnson, B. \& Christensen, L. (2000). Educational research. Boston: Allyn and Bacon.

Ngeow, K.Y. (1998). Motivation and transfer in language learning. ERIC digest. Bloomington, IN: ERIC clearinghouse on Reading. (ERIC Document Reproduction Service No. ED 427 318).

Power, B., \& Hubbard, R. (1999). Living the questions: A guide for teacher - researchers. Portland, ME: Stenhouse Publishers.

Risner, G., Skeel, D., \& Nicholson, J. (1992). A closer look at textbooks. The Science Teacher, 61(7), 42 - 45.

Spear, M. (1987). Teachers views on importance of science to boys and girls. In A. Kelly (ed) Science for Girls? Buckingham: Open University Press.

Tharp, R.G. (1989). Psycho-cultural variables and constants: Effects on teaching and learning in schools. American Psychologist, 44, 349-359. http://dx.doi.org/10.1037/0003-066X.44.2.349

Thorndike, R.L., \& Hagen, E.P. (1997). Measurement and evaluation in psychology and education. Upper saddle River, NJ: Prentice Hall.

Trowbridge. L.W., \& Bybee, R.W. (1996). Teaching secondary school science: Strategies for developing scientific literacy. Englewood Cliffs: Merrill Prentice Hall.

Wilen, W. (1991). Questioning skills for teachers (3rd ed.). Washington, D.C.: National Educaton Association.

Wiseman, D.C. (1999). Research Strategies for education. New York: Wadsworth Publishing Company.

\section{Appendix}

Science Class Questioning Categories (SCQC)

\section{Instruction to Observers:}

a) Fill in the spaces provided by writing.

b) During the lesson, make a mark next to the appropriate categories every 3 seconds for categories A-J. For category $\mathrm{K}$, note the wait-time a teacher allows a student to respond to a question before reacting.

c) After lesson, mark the frequency of occurrence of the categories according to your mark during the lesson.

d) Use the following scale (ties are allowed).

i. If the behavior was the dominant one, mark 4.

ii. If the behavior was quite frequent, mark 3 .

iii. If the behavior was infrequent, mark 2 .

iv. If the behavior did not occur, mark 1.

e) Fill in the sheet without consulting anyone, and hand it immediately to the researcher.

f) Thanks for your cooperation.

\section{Categories}

A. Knowledge; Ask factual recall questions using action verbs like: define, describe, identify, list, name etc.

B. Comprehension; ask questions that require understanding of facts by using action verbs like: convert, explain, extend, paraphrase, rephrase, summarize etc.

C. Application; ask application questions that extend facts and understanding to the next level of authenticity using action verbs like: apply, demonstrate, employ, operate, solve, use etc.

D. Analysis; ask questions that require students to break a problem into its component parts and draw relationships among parts using action verbs like: breakdown, differentiate, distinguish, point out, relate, support etc.

E. Synthesis; ask questions that require student to produce something unique or original - to design a solution using action verbs like: compare, predict, formulate, create, devise, produce etc. 
F. Evaluation; Ask questions that require student to form judgment and make decisions using stated criteria with action verbs like: appraise, assess, decide, defend, judge, justify it.

G. Female; Direct questions to female students.

H. Male; Direct questions to male students.

I. Selective; Direct questions to specific students.

J. General; Direct questions to all students

K. Wait-time, wait $\mathrm{X}$ - time for students response before reacting.

Table 1. Comparison of class time spent questioning in science class

\begin{tabular}{|l|l|l|l|l|}
\hline $\begin{array}{l}\text { Local Government } \\
\text { Area }\end{array}$ & N & School Subjects & $\begin{array}{l}\text { X questioning time } \\
\text { in minutes }\end{array}$ & \% of questioning time \\
\hline IKA SOUTH & 10 & Biology & 23 & 51.1 \\
& 10 & Chemistry & 21 & 46.7 \\
& 10 & Physics & 19.8 & 44.0 \\
\hline IKA SOUTH EAST & 10 & Biology & 22 & 48.9 \\
& 10 & Chemistry & 22.6 & 50.2 \\
& 10 & Physics & 20.1 & 46.9 \\
\hline TOTAL & $\mathbf{6 0}$ & All subjects & $\mathbf{2 1 . 4}$ & $\mathbf{4 7 . 9 7}$ \\
\hline
\end{tabular}

Table 2. Comparison of science class-time spent on various question types $\mathrm{N}=60$, Time $=45$ minutes

\begin{tabular}{|l|l|l|l|}
\hline & Type of Question & Class time spent in seconds & \% class time spent on questions \\
\hline A & Knowledge & 865 & 68 \\
\hline B & Comprehension & 170 & 13.5 \\
\hline C & Application & 100 & 8 \\
\hline D & Analysis & 76 & 6 \\
\hline E & Synthesis & 40 & 3 \\
\hline F & Evaluation & 20 & 1.5 \\
\hline & Total & $\mathbf{1 2 7 1}$ & $\mathbf{1 0 0}$ \\
\hline
\end{tabular}

Table 3. Comparison of class-time spent by female and male science teachers on various question types $\mathrm{N}=40$

\begin{tabular}{|c|l|c|c|c|c|}
\hline \multirow{2}{*}{} & \multirow{2}{*}{ Type of Question } & \multicolumn{2}{|c|}{ FEMALE } & \multicolumn{2}{c|}{ MALE } \\
\cline { 3 - 6 } & & Class time sec. & \% class time & Class time sec. & \% class time \\
\hline A & Knowledge & 822 & 70 & 819 & 65 \\
\hline B & Comprehension & 202 & 16 & 184 & 14.6 \\
\hline C & Application & 107 & 8.5 & 105 & 8.3 \\
\hline D & Analysis & 38 & 3.0 & 76 & 6 \\
\hline E & Synthesis & 25 & 2.0 & 50 & 4 \\
\hline F & Evaluation & 6 & 0.5 & 26 & 2.1 \\
\hline
\end{tabular}

Table 4. Analysis of male and female teachers' questioning patterns in Science classroom $\mathrm{N}=40$.

\begin{tabular}{|l|l|l|l|l|}
\hline \multirow{2}{*}{} & \multirow{2}{*}{ Type of Question } & FEMALE & MALE & F-value \\
\cline { 3 - 5 } & & $\overline{\mathbf{X}} \%$ class time & $\overline{\mathbf{X}} \%$ class time & \\
\hline A & Knowledge & 70 & 65 & 5.44 \\
\hline B & Comprehension & 16 & 14.6 & 2.31 \\
\hline C & Application & 8.5 & 8.3 & 1.07 \\
\hline D & Analysis & 3.0 & 6 & 4.81 \\
\hline E & Synthesis & 2.0 & 4 & 2.48 \\
\hline F & Evaluation & 0.5 & 2.1 & 1.74 \\
\hline
\end{tabular}


Table 5. Analysis and distribution of questions asked based on sex and students ability

\begin{tabular}{|l|l|l|l|l|l|l|l|l|}
\hline $\begin{array}{l}\text { Local } \\
\text { Govt. Area }\end{array}$ & $\begin{array}{l}\text { School } \\
\text { Subject }\end{array}$ & $\begin{array}{l}\text { No. of } \\
\text { Lessons }\end{array}$ & $\begin{array}{l}\text { No. of } \\
\text { Question } \\
\text { Asked }\end{array}$ & $\begin{array}{l}\text { No. } \\
\text { directed } \\
\text { at } \\
\text { Females }\end{array}$ & $\begin{array}{l}\text { No. directed } \\
\text { at Males }\end{array}$ & $\begin{array}{l}\text { No. directed } \\
\text { at high ability }\end{array}$ & $\begin{array}{l}\text { No. directed at } \\
\text { middle ability }\end{array}$ & $\begin{array}{l}\text { No. directed } \\
\text { at low ability }\end{array}$ \\
\hline IKA & Biology & 10 & 150 & 60 & 90 & 105 & 26 & 19 \\
SOUTH & Chemistry & 10 & 122 & 43 & 79 & 89 & 24 & 9 \\
& Physics & 10 & 103 & 20 & 83 & 78 & 18 & 7 \\
\hline IKA & Biology & 10 & 142 & 61 & 81 & 99 & 23 & 20 \\
NORTH & Chemistry & 10 & 127 & 51 & 76 & 93 & 25 & 9 \\
EAST & Physics & 10 & 117 & 23 & 94 & 89 & 20 & 8 \\
\hline Grand & & $\mathbf{6 0}$ & $\mathbf{7 6 1}$ & $\mathbf{2 5 8}$ & $\mathbf{5 0 3}$ & $\mathbf{5 5 3}$ & $\mathbf{1 3 6}$ & $\mathbf{7 2}$ \\
Total & & & & & & & & \\
\hline Grand \%
\end{tabular}

Table 6. Comparison of frequency of wait-time on questions in science classes

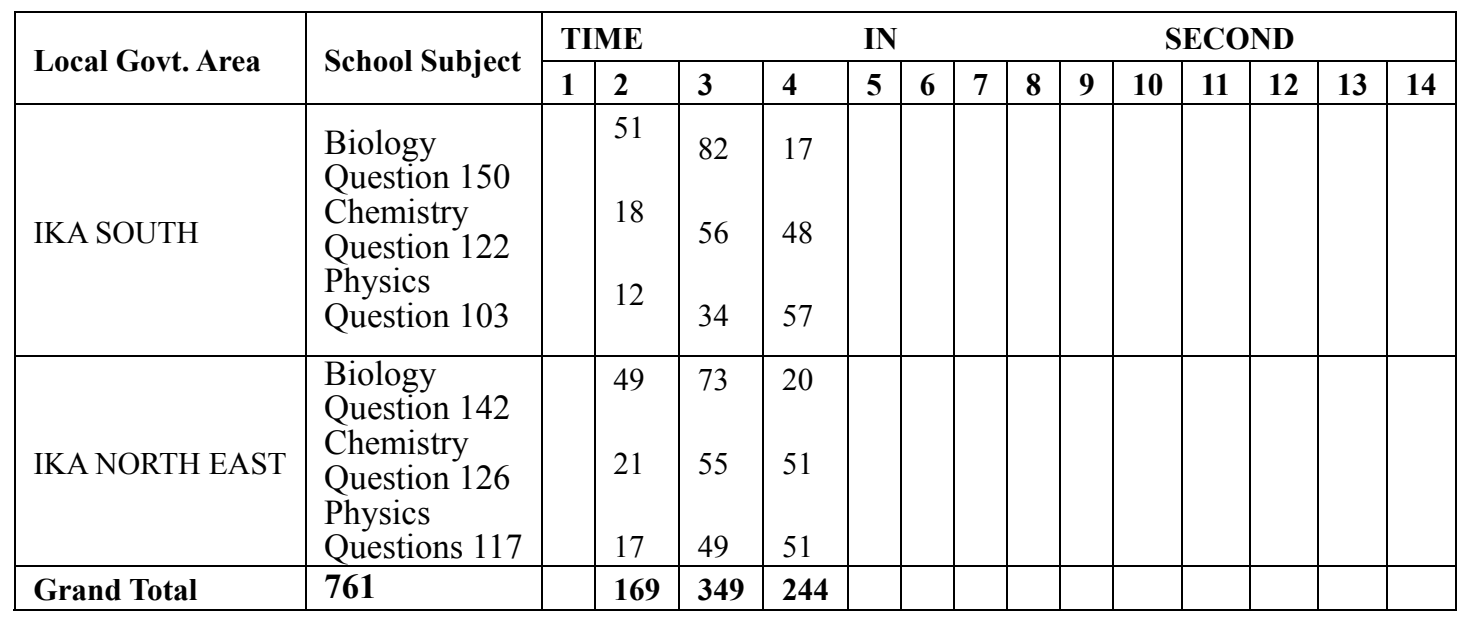

